\title{
Profil Gender Sumber Daya Manusia Universitas Sam Ratulangi Tahun 2019 berbasis Penilaian Gender (Gender Assessment)
}

\author{
Dingse Pandiangan¹, Leviane J.H. Lotulung ${ }^{2}$, Yulianty Sanggelorang ${ }^{3}$ \\ ${ }^{1}$ Jurusan Biologi FMIPA dan Pusat Kajian Perempuan LPPM Universitas Sam Ratulangi Manado \\ email: dingsepan@unsrat.ac.id \\ ${ }^{2}$ Jurusan Ilmu Komunikasi FISPOL dan Prodi Pengembangan Sumberdaya Pembangunan (PSP) \\ Universitas Sam Ratulangi Manado \\ ${ }^{3}$ Program Studi Ilmu Kesehatan FKM Universitas Sam Ratulangi Manado
}

\begin{abstract}
ABSTRAK
Kesetaraan gender sangat diperlukan dalam membangun kepemerintahan yang baik, termasuk di dalam penyelenggaraan proses pendidikan di institusi perguruan tinggi. Guna mencapai kesetaraan gender, diperlukan adanya penjabaran konsep dan prinsip dasar penyelenggaraan good governance. Tujuan dari tulisan ini adalah untuk mewujudkan Profil Gender Unsrat yang merupakan salah satu output penilaian gender melalui suatu proses penilaian gender (gender assessment). Pelaksanaan gender assessment ini dilaksanakan oleh Tim Riset yang dibentuk oleh Pusat Kajian Perempuan (PKP) LPPM UNSRAT. Pekerjaan efektif sekitar 2 minggu kerja untuk membuat suatu profil gender Universitas Sam Ratulangi Manado. Dalam pelaksanaannya, menggunakan metode baseline data. Berdasarkan hasil assessment ditemukan bahwa proporsi kepemimpinan di UNSRAT harus lebih mempertimbangkan representasi gender, mengafirmasi keseimbangan jumlah mahasiswa berdasarkan kesetaraan gender, dan perlu dilakukan kegiatankegiatan untuk meningkatkan kesadaran dan kapasitas civitas akademika dalam penerapan isu gender.
\end{abstract}

Kata kunci: Profil Gender, Kesetaraan Gender, UNSRAT, Manado

\begin{abstract}
Gender equality is very much needed in building good governance, including in organizing the education process in tertiary institutions. To achieve gender equality, it is necessary to elaborate on the concepts and basic principles of the implementation of good governance. The purpose of this paper is to realize the Gender Profile Element which is one of the outputs of gender assessment through a gender assessment process (gender assessment). The gender assessment was carried out by the Research Team formed by the Center for Women's Studies (PKP) LPPM UNSRAT. Effective work about 2 weeks of work to create a gender profile of Sam Ratulangi University, Manado. In its implementation, using the baseline data method. Based on the results of the assessment it was found that the proportion of leadership in UNSRAT should consider gender representation more, affirm the balance of the number of students based on gender equality, and activities need to be carried out to increase awareness and capacity of the academic community in applying gender issues.
\end{abstract}

Keywords: Gender Profile, Gender Equality, UNSRAT, Manado

\section{PENDAHULUAN}

Universitas sebagai gudangnya ilmu pengetahuan dan intelektual harus memiliki banyak keunggulan di bidangnya terutama menyangkut hal kebenaran. Ada hal yang sangat dibutuhkan dalam pencarian dan pembuktian kebenaran yakni melalui pendekatan ilmiah. Pendekatan ini digunakan untuk membangun dan mengembangkan intelektualitas manusia dalam ranah budaya tertentu. Di Perguruan Tinggi, aspek intelektualitas harus selalu diselaraskan dengan moral dan etika, karena hal itu sangat menentukan kemajuan peradaban manusia. 
Universitas sendiri sebagai sumber sekaligus pengawal peradaban. Hakikat ini menjadi dasar dari kebenaran umum bahwa tidak mungkin suatu bangsa akan berkembang kearah peradaban lebih maju tanpa kehadiran perguran tinggi yang berkualitas. Dalam lingkungan yang lebih kecil, membangun dan mengembangkan budaya Sulawesi Utara terkait erat dengan kemajuan (kualitas) Universitas Sam Ratulangi sebagai institusi pendidikan tinggi terbaik, terbesar, dan terfavorit di daerah ini disamping pendidikan tinggi lainnya.

Pengarusutamaan adalah strategi yang dibangun untuk mengintegrasikan gender menjadi satu dimensi integral dari perencanaan, penganggaran, pelaksanaan, pemantauan, dan evaluasi atas kebijakan, program dan kegiatan pembangunan di berbagi sektor. Kelembagaan pengarusutamaan gender adalah upaya memenuhi unsur-unsur pengarusutamaan gender, agar berfungsi secara efektif dalam satu sistem berkelanjutan dengan norma yang disepakati dalam pemenuhan hak-hak asasi perempuan dan laki-laki secara adil untuk mencapai kesetaraan antara perempuan dan laki-laki di seluruh bidang pembangunan dan tingkatan pemerintahan.

Implementasi Kesetaraan Gender di dalam membangun kepemerintahan yang baik, diperlukan adanya penjabaran lebih lanjut tentang konsep dan prinsip dasar penyelenggaraan kepemerintahan yang baik (Good Governance), agar masyarakat laki-laki dan perempuan dapat memperoleh akses dan kontrol yang sama terhadap sumberdaya pembangunan, sehingga memperoleh peluang yang sama baik dalam berpartisipasi dan menerima manfaat dilaksanakannya penyelenggaraan pemerintahan dan pelaksanaan pembangunan Upaya pencapaian implementasi kesetaraan gender pada tingkat universitas merupakan eksistensi keberadaan Pusat Kajian Perempuan (PKP) LPPM UNSRATUniversita Sam Ratulangi kemudian konsep dan prinsipnya tertuang dalam Surat Keputusan Rektor UNSRAT tentang Kesetaraan Gender UNSRAT Manado.

Tujuan dari tulisan ini adalah untuk mewujudkan Profil Gender Unsrat yang merupakan salah satu output penilaian gender melalui suatu proses penilaian gender (gender assessment). Penlilaian ini adalah pemindaian sumberdaya (resource scanning) yang menandakan adanya kapasitas pengarusutamaan gender dan bukan sebuah penilaian sejauh mana pengarusutamaan gender di dalam UNSRAT itu sendiri. Penilaian gender (gender assessment) ini merupakan satu dari beberapa langkah menuju penyusunan Kebijakan Kesetaraan Gender (Gender Equality Policy) di lingkungan
UNSRAT Manado. Selain itu, penilaian gender ini bertujuan untuk membuktikan (memferifikasi) kemunculan kesadaran dan kegiatan-kegiatan pengarusutamaan gender yang sudah dilakukan serta sumberdaya yang ada yang mungkin berguna atau menyumbangkan pengembangan dan pelaksanaan Kebijakan Kesetaraan Gender di seluruh lingkungan UNSRAT.

\section{METODE PENELITIAN}

Adapun pelaksanaan gender assessment ini dilaksanakan oleh Tim Riset yang dibentuk oleh Pusat Kajian Perempuan (PKP) LPPM UNSRAT. Tim Riset ini terdiri dari 5 orang yang ditetapkan dalam surat tugas Ketua LPPM UNSRAT nomor 308/UN12.13/LL/2019 pada tanggal 7 Oktober 2019 yaitu sebagai ketua Prof. Dr. Dingse Pandiangan, MSi, Sekretaris Yulianty Sanggelorang SKM, MPH, dan anggota Leviane J. H. Lotulung, S.Sos, M.I.Kom yang dibantu administrasi oleh Meiske Nova Tumoka, S.Sos dan Nova S. Mantiri. Tenaga pengambil data dibantu oleh beberapa tenaga honorer LPPM UNSRAT. Tim ini bekerja berdasarkan PKS dan KAK bersama KPPPA Bidang Partisipasi masyarakat bekerja sampai tanggal 15 November 2019. Pekerjaan efektif sekitar 2 minggu kerja untuk membuat suatu profil gender Universitas Sam Ratulangi Manado. Dalam pelaksanaannya, menggunakan metode baseline data, yakni penelitian ini dengan cara menghimpun informasi dasar sebelum suatu program dimulai dari koleksi data primer ke Fakultas, Bagian, Lembaga, Pusat dan Unit-unit di UNSRAT, namun koleksi data sangat sulit di bulan Oktober dan November yang sangat aktif dalam pelaksanaan program masing-masing. Akhirnya berkat bantuan Konsultan Prof Sangkertadi dan Prof. Dr. Charles L. Kaunang, ditemukan data yang tahun 2018 (Unsrat dalam Angka 2018) yang kesemuanya belum terpilah. Data primer tersebut kemudian diolah dan dipilah sehingga diperoleh data terpilah dan dibuat dalam grafik yang selanjutnya diinterpretasikan.

Data tersebut kemudian digunakan sebagai pembanding untuk memperkirakan dampak program Baseline, kondisi dimana pengukuran target behavior dilakukan pada keadaan natural sebelum diberikan intervensi apapun. Penggunaan metode data baseline dalam penelitian ini bersifat data baseline tetap yakni terkait erat dengan program yang diajukan dan dengan jelas diindikasikan oleh sasaran dan tujuan program penyusunan Gender Equality Policy 
Jurnal Perempuan dan Anak Indonesia

UNSRAT Manado. Tahapan-tahapan dalam penelitian data baseline ini dilakukan dengan

1. Merumuskan target program.

2. Mengidentifikasi tim dan keahlian yang dibutuhkan

3. Merumuskan informasi/data yang diperlukan.

4. Menentukan metode penggalian data.

5. Merumuskan instrumen penelitian. Mis: kuisioner, daftar pertanyaan, dan lainnya.

6. Melakukan ujicoba terhadap instrumen.

7. Menentukan responden (kategori dan jumlah).

8. Mempersiapkan logistik dan jadwal penelitian.

9. Melakukan penelusuran data.

10. Menganalisa data

11. Menuliskan laporan

12. Mengevaluasi proses studi.

\section{HASIL DAN PEMBAHASAN}

Analisis pertama ditujukan pada profil sumber daya manusia diikuti dengan kepemimpinan pada tingkat Rektorat. Data yang dikumpulkan oleh tim peneliti PKP (Pusat Kajian Perempuan). Data ini berkurun waktu 2018-2019. Dari data yang ada, jumlah dosen perempuan mengungguli jumlah dosen laki-laki. Jumlah dosen perempuan sebanyak $57 \%$ sedangkan dosen laki-laki berjumlah $43 \%$ dari jumlah keseluruhan sebanyak 1.544 dosen (Gambar 1)

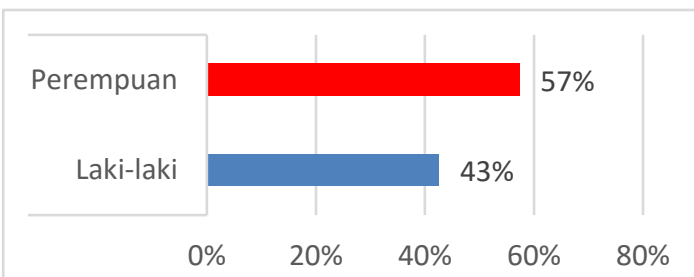

Gambar 1. Perbandingan Gender Dosen di UNSRAT

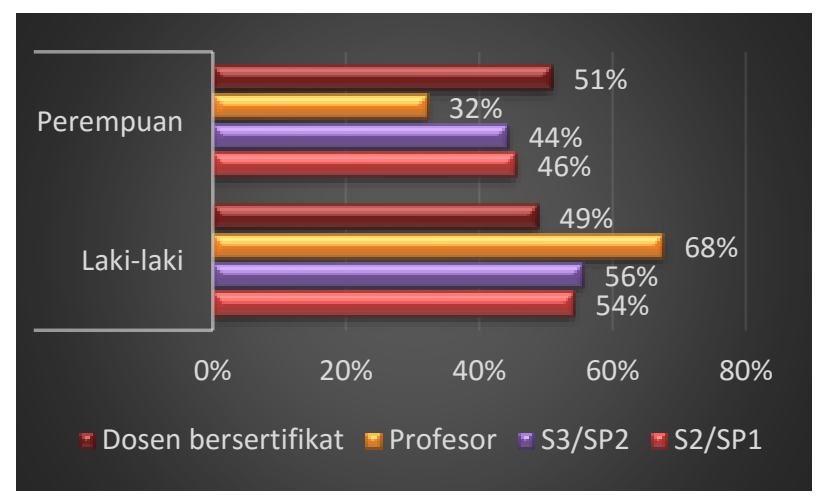

Gambar 2. Perbandingan Gender Dosen di UNSRAT Berdasarkan Kualifikasi Pendidikan

Meski secara jumlah, dosen perempuan mengungguli jumlah dosen laki-laki, namun jika dilihat dari kualifikasi pendidikan jenjang tertinggi yakni jenjang doktor (S3)/Sp2 dosen perempuan masih tertinggal. Jumlah dosen perempuan yang sudah menyelesaikan studi S3/Sp2 hanya 44\% disbanding dosen laki-laki sebesar 56\%. Begitu juga dengan jumlah jabatan fungsional tertinggi sebagai dosen yaitu professor, dosen perempuan masih belum bisa menyamakan prosentase jumlah dosen laki-laki. Professor perempuan berjumlah $32 \%$ sedangkan dosen professor laki-laki berjumlah 68\% (Gambar 2).

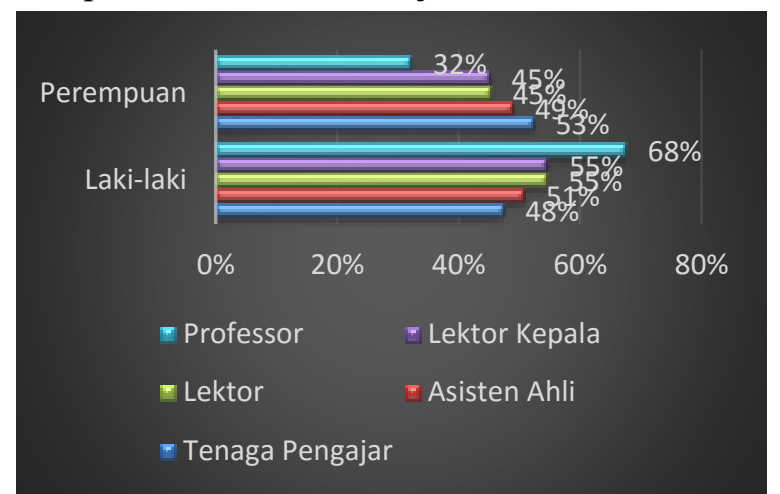

Gambar 3. Perbandingan Gender Dosen di UNSRAT Berdasarkan Jabatan Fungsional

Pada jabatan fungsional, dosen perempuan juga belum bisa mengungguli dosen laki-laki. Selain jenjang jabatan professor, jenjang jabatan lektor kepala, jumlah dosen perempuan yang meraihnya hanya $45 \%$ dibanding dosen laki-laki sebesar $55 \%$. Begitu juga jabatan lektor, dosen perempuan meraih $45 \%$ dan laki-laki 55\%. Jumlah dosen perempuan hanya mengungguli pada jabatan tenaga pengajar saja yang berjumlah $52 \%$ dibanding dosen tenaga pengajar laki-laki sebesar $48 \%$ saja (Gambar 3).

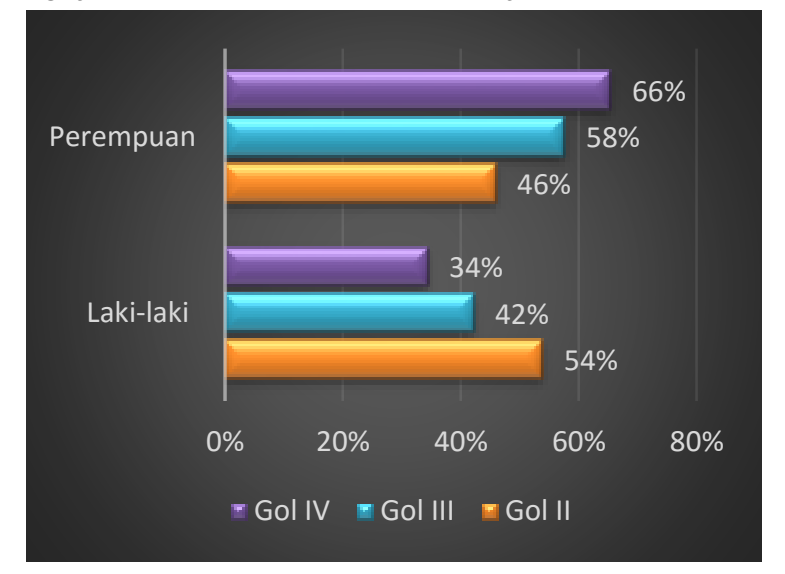


Gambar 4. Perbandingan Gender Tenaga

Kependidikan di UNSRAT Berdasarkan

Pangkat dan Golongan

Pada pangkat dan golongan tenaga kependidikan, pegawai perempuan lebih unggul dibanding pegawai laki-laki. Pegawai perempuan yang sudah meraih golongan III sebanyak 58\% sedangkan pegawai laki-laki hanya 42\% (Gambar 4). Begitu juga pada golongan IV, pegawai perempuan lebih unggul dibanding pegawai laki-laki. Hal itu terlihat dari kepercayaan pimpinan universitas pada pegawai perempuan memegang jabatan sebagai karo, kabag dan kasubbag di lingkungan UNSRAT.

\section{Kepemimpinan Universitas}

Analisis berikutnya ditujukan pada profil kepemimpinan pada tingkat Rektorat. Data yang dikumpulkan oleh tim peneliti PKP (Pusat Kajian Perempuan). Data ini berkurun waktu 2019 juga sejalan dengan data primer di sub bagian. Dari data yang dikumpulkan, kesenjangan antara pejabat dan posisi laki-laki dan perempuan pada hampir semua tingkatan. Pada level kepemimpinan tertinggi yakni Rektorat misalnya hanya ada satu perempuan yang menjabat yakni sebagai Rektor Universitas Sam Ratulangi.

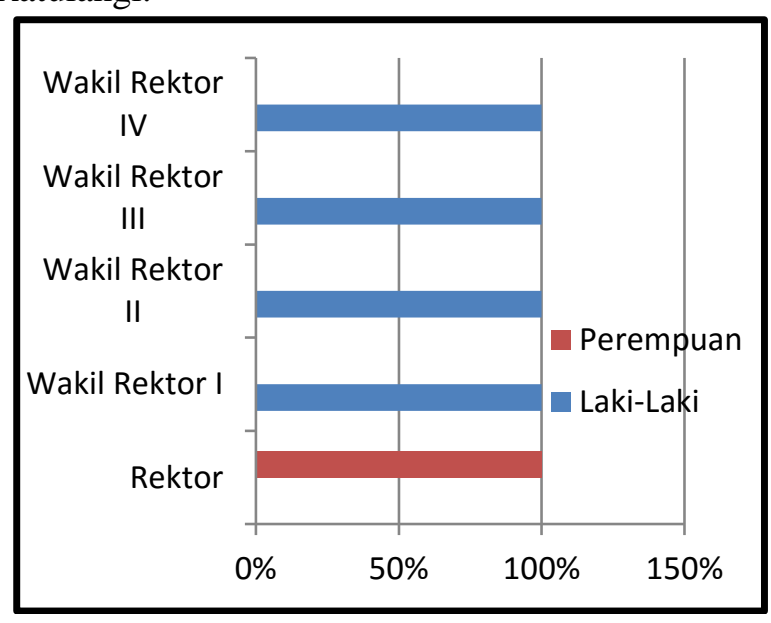

Gambar 5. Distribusi Jabatan Struktural di Jajaran

Pucuk Pimpinan UNSRAT (Sumber: Data

Primer Kepegawaian UNSRAT tahun 2019)

Perlu diketahui bahwa, dalam tradisi pembagian kekuasaan tertinggi, posisi terpenting adalah Rektor dan pimpinan tertinggi di UNSRAT adalah perempuan yang sangat menunjukkan keberpihakan UNSRAT pada Gender. Kemudian pimpinan berikutnya Wakil Rektor I yang membidangi bidang Akademik, Wakil Rektor II yang membidangi Bidang Umum dan Keuangan kemudian Wakil Rektor III yang membidangi Kemahasiswaan dan Alumni serta Wakil Rektor IV yang membidangi Bidang Perencanaan. Keempat wakil rektor semuanya laki-laki pada periode 2018-2022. Namun pada periode 2014-2018 wakil rektor terdiri 1 perempuan dan sisanya 3 laki-laki.

Beberapa komentar yang didapatkan oleh tim peneliti soal mengapa masih jarang perempuan yang menduduki posisi di tingkat rektorat antara lain karena tingkat kepangkatan mereka yang belum bisa dipromosikan untuk jabatan yang tinggi. Tentang kesenjangan di atas lihat Gambar 1. Kemudian wakil rektor merupakan penunjukan oleh rektor sendiri yang bisa bekerjasama dalam melakukan tugastugasnya. Rektor UNSRAT Prof. Dr. Ellen Joan Kumaat, M.Sc.DEA sendiri merupakan salah satu rektor perempuan pertama di Perguruan Tinggi Negeri di Indonesia yang dilantik 27 Juli 2014, selain Rektor UGM Prof. Ir. Dwikorita Karnawati, MSc., Ph.D yang dilantik pada 27 Oktober 2014. Serta Rektor Universitas Terbuka Prof. Ir. Tian Belawati M. Ed,.Ph.D yang kedua kalinya dilantik pada $12 \mathrm{Juli}$ 2013 oleh Mendikbud Prof. Mohammad Nuh.

\section{Kepemimpinan Tingkat Fakultas}

Sementara itu, profil gender yang hampir serupa juga bisa dijumpai pada profil kepemimpinan pada tingkat Fakultas. Kepemimpinan pada tingkat fakultas secara umum bisa dibagi ke dalam dua bidang yakni bidang akademik dan tata usaha. Di kedua bidang tersebut, dominasi laki-laki sebagai pemegang posisi dan jabatan masih sangat terlihat. Pada Fakultas MIPA, Dekan dan Kepala Tata Usaha dipegang keduanya oleh laki-laki. Perempuan memiliki jabatan yang lebih rendah seperti menjadi Kasubag (kepala sub-bagian) yang posisinya tidak terlalu menentukan.

Penempatan posisi perempuan pada level tersebut mencerminkan dua hal; pertama, kepangkatan pendidikan dan kependidikan perempuan masih rendah sementara salah satu prasyarat menduduki sebuah jabatan adalah adanya kesesuaian pangkat; kedua, masih ada pemikiran jika posisi perempuan yang tepat cukup untuk menjadi pengajar (bukan pimpinan fakultas) dan hal-hal yang berkaitan dengan administrasi. Soal posisi perempuan yang masih banyak menjadi tenaga administrasi. Profil gender di kepemimpinan UNSRAT memiliki data yang berebeda-beda pada setiap fakultas. Pada setiap bidang fakultas berbeda-beda dominasi antara 
laki-laki dan perempuan dalam pemegangan posisi dan jabatan. Berikut adalah Gambar persentase gender pada 11 fakultas yang ada di Universitas Sam Ratulangi:

\section{Fakultas Kedokteran}

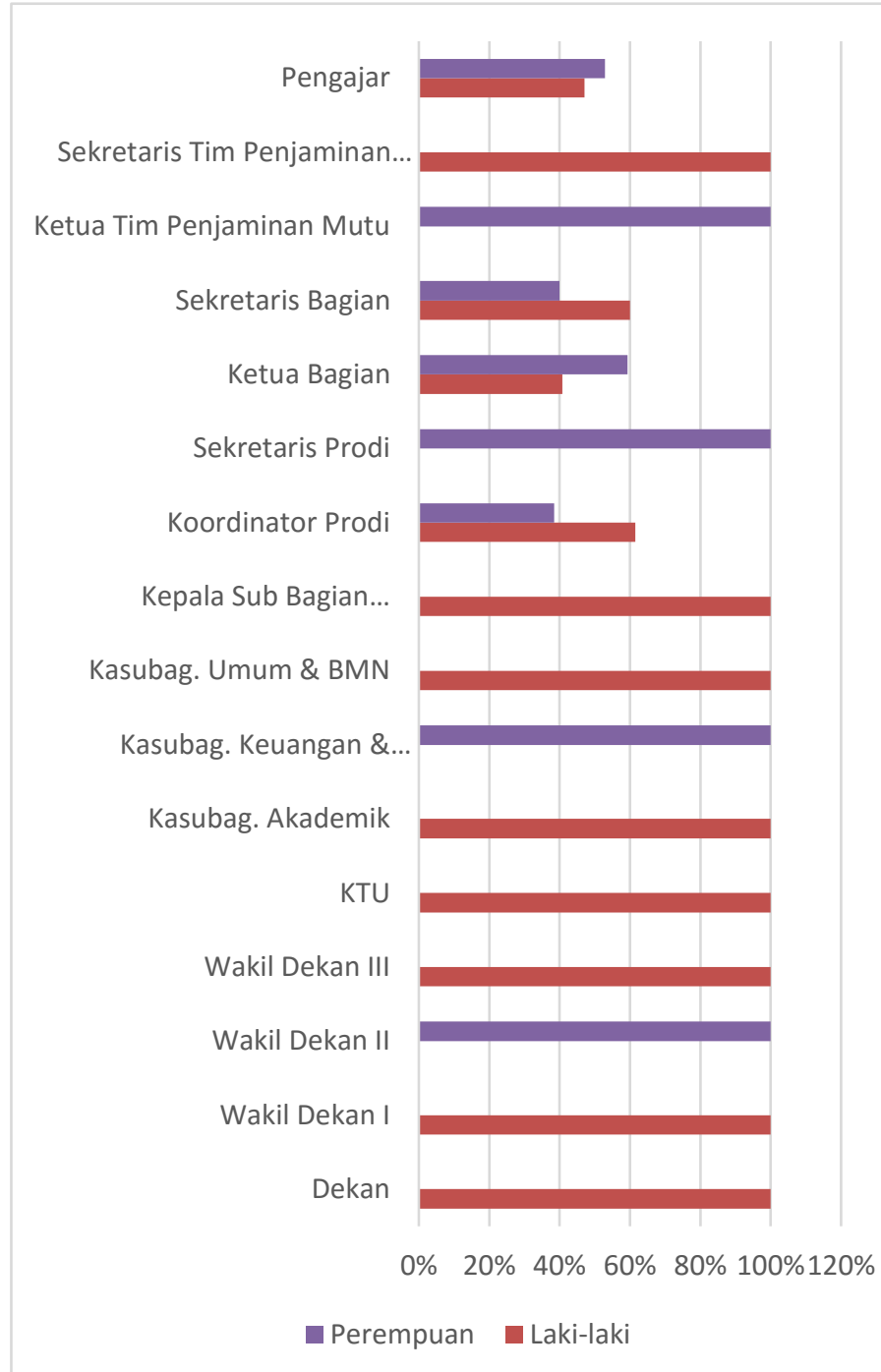

Gambar 6. Persentase Gender pada Fakultas Kedokteran UNSRAT (Sumber: Data Primer UNSRAT dalam angka 2018)

Fakultas Kedokteran, terlihat dominasi lakilaki dalam memegang posisi dan jabatan di kepemimpinan fakultas. Namun tidak sedikit pula perempuan yang ikut andil dalam pemegangan posisi dan jabatan pada kepemimpinan pada Fakultas Kedokteran.

\section{Fakultas Teknik}

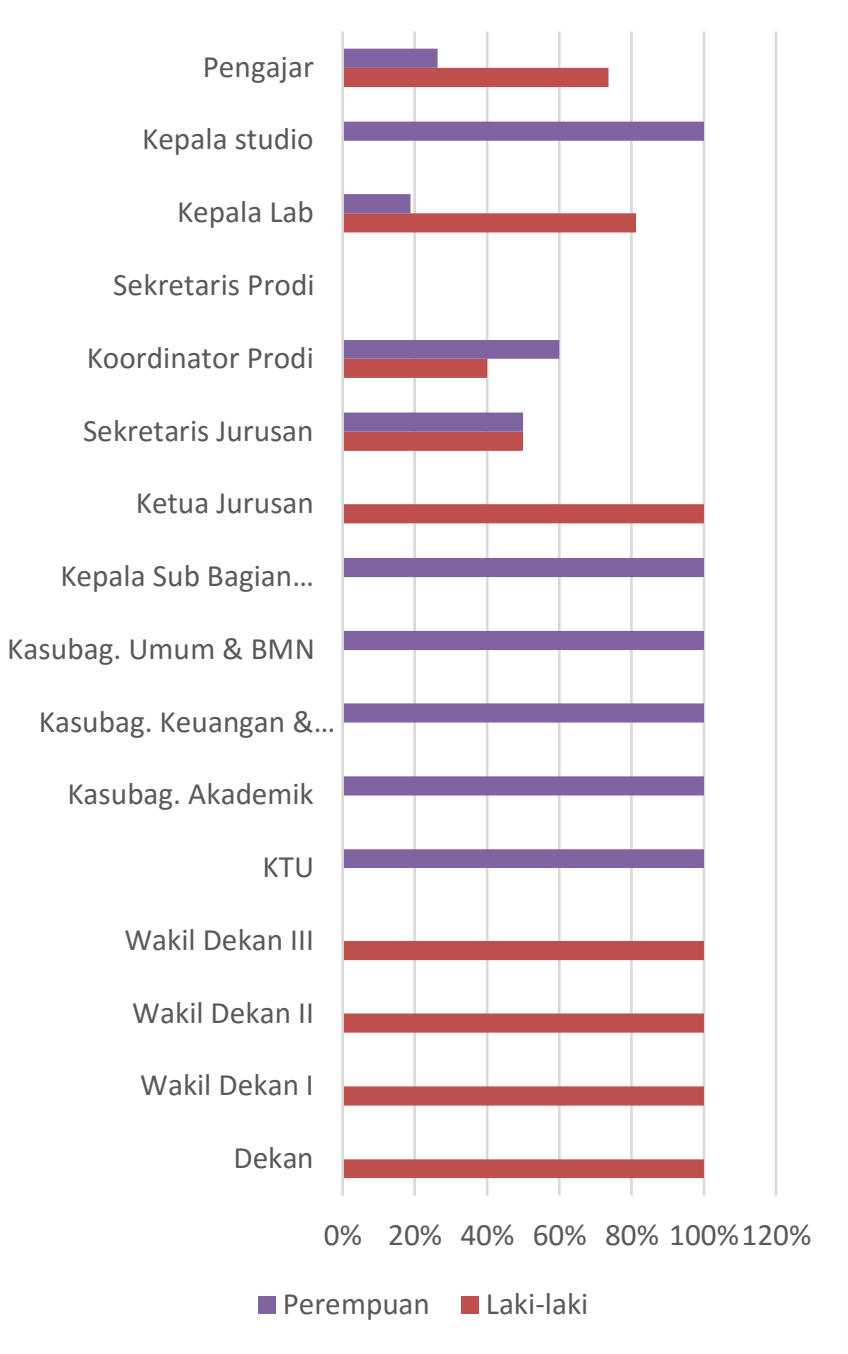

Gambar 7. Persentase Gender pada Fakultas Teknik UNSRAT (Sumber: Data Primer UNSRAT dalam angka 2018)

Fakultas Teknik, terlihat dominasi laki-laki dalam pemegangan posisi dan jabatan di kepemimpinan fakultas sama halnya seperti Fakultas Kedokteran. Namun tidak sedikit pula perempuan yang ikut andil dalam pemegangan posisi dan jabatan pada kepemimpinan pada Fakultas Teknik.

\section{Fakultas Pertanian}

Fakultas Pertanian, terlihat dominasi perempuan dalam pemegangan posisi dan jabatan di kepemimpinan fakultas. Namun tidak sedikit pula laki-laki yang ikut andil dalam pemegangan posisi dan jabatan pada fakultas ini. 
Jurnal Perempuan dan Anak Indonesia

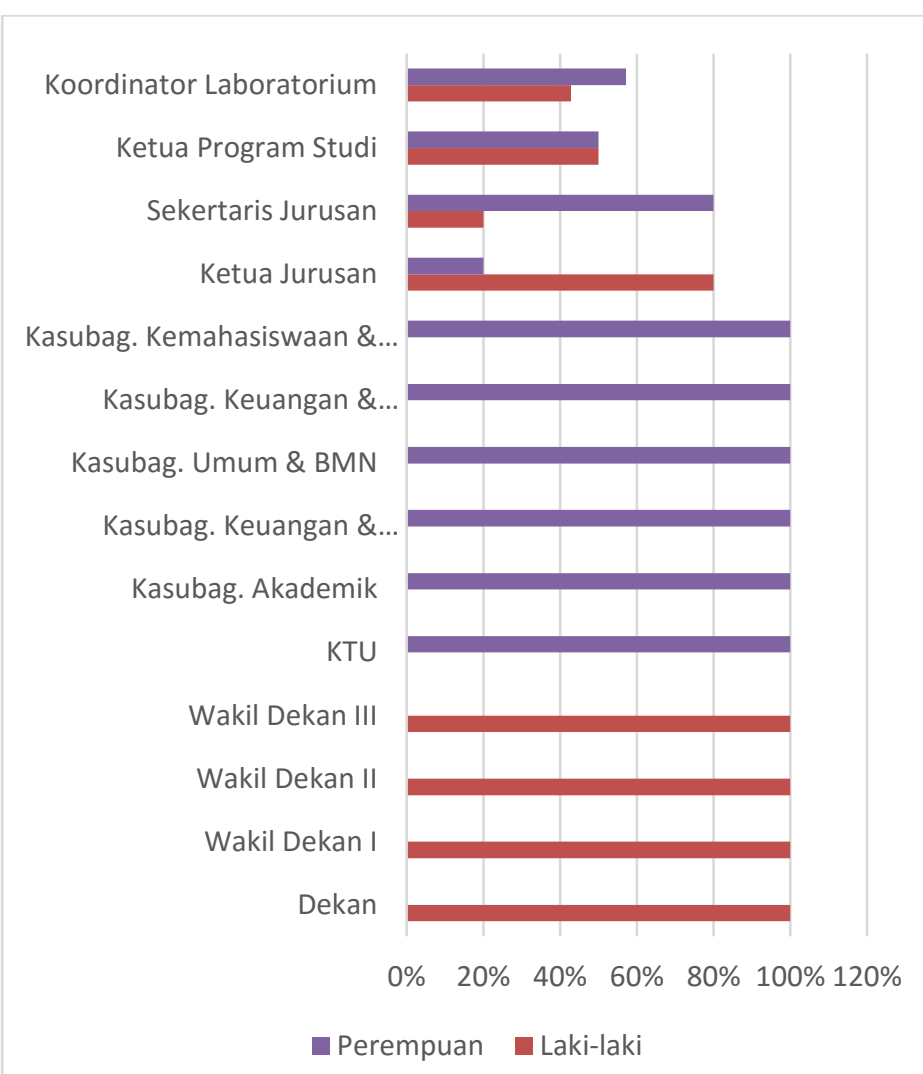

Gambar 8. Persentase Gender pada Fakultas Pertanian UNSRAT (Sumber: Data Primer UNSRAT dalam angka 2018)

\section{Fakultas Peternakan}

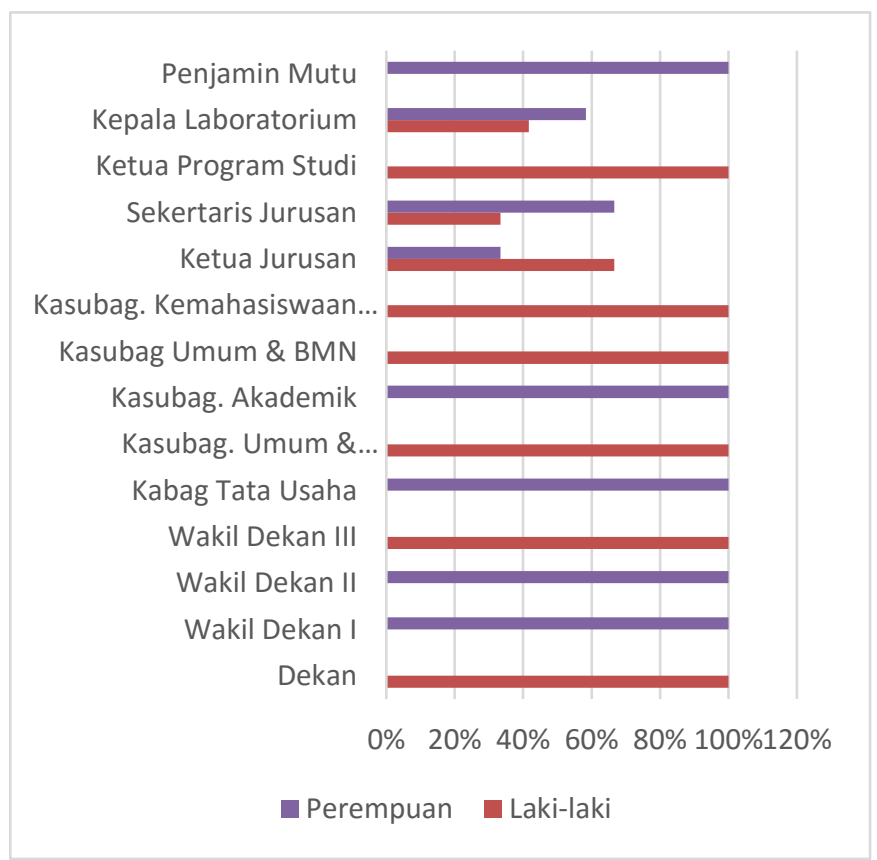

Gambar 9. Persentase Gender pada Fakultas Peternakan UNSRAT (Sumber: Data Primer UNSRAT dalam angka 2018)
Fakultas Peternakan, terlihat dominasi lakilaki dalam pemegangan posisi dan jabatan di kepemimpinan fakultas. Namun tidak sedikit pula perempuan yang ikut andil dalam pemegangan posisi dan jabatan di sana.

\section{Fakultas Perikanan dan Ilmu Kelautan}

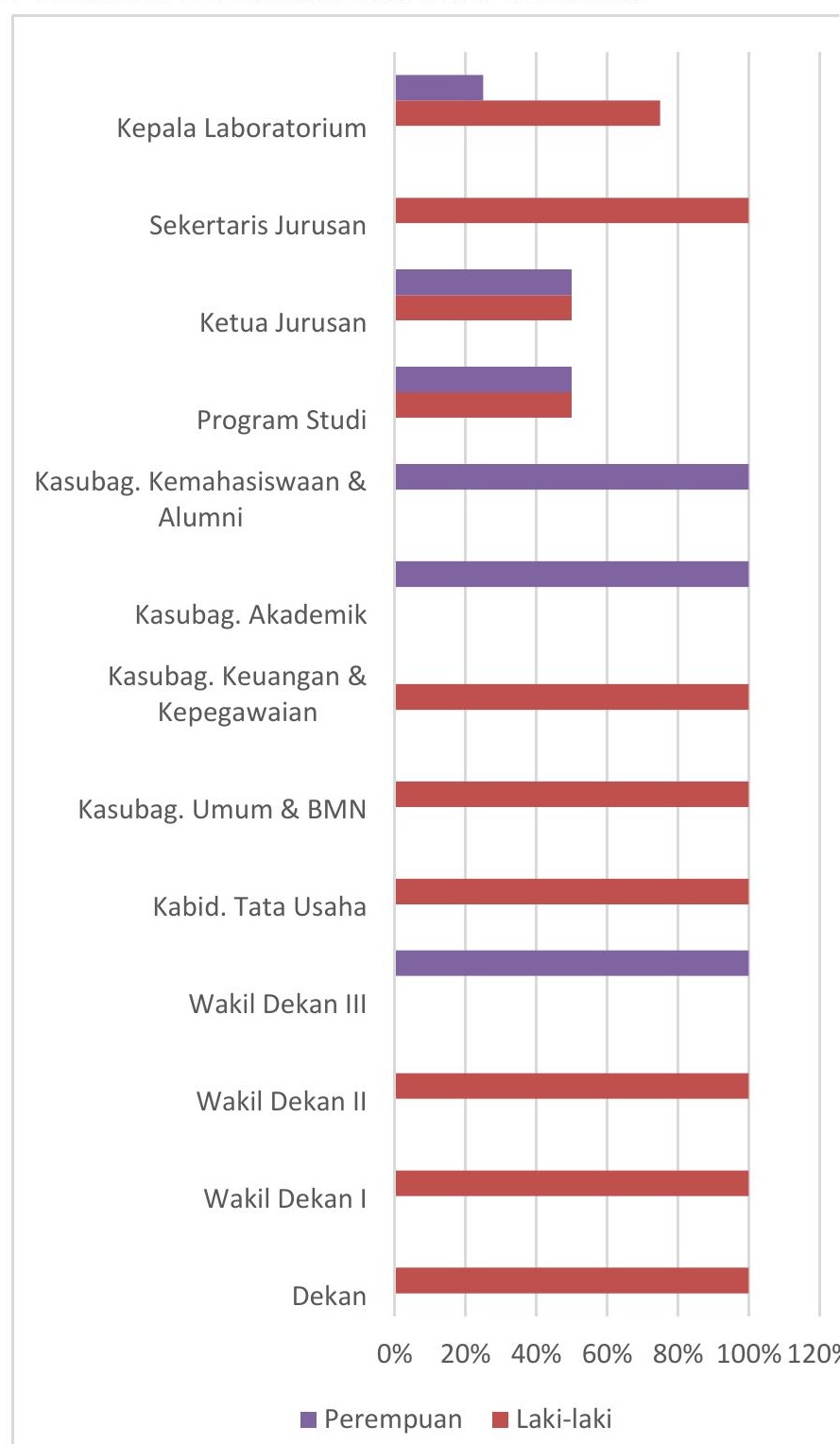

Gambar 10. Persentase Gender pada Fakultas

Perikanan dan Kelautan UNSRAT (Sumber:

Data Primer UNSRAT dalam angka 2018)

Fakultas Perikanan dan Ilmu Kelautan, terlihat dominasi laki-laki dalam pemegangan posisi dan jabatan di kepemimpinan fakultas. Namun tidak sedikit pula perempuan yang ikut andil dalam pemegangan posisi dan jabatan pada kepemimpinan di sana. 
Jurnal Perempuan dan Anak Indonesia

\section{Fakultas Ekonomi dan Bisnis}

\section{EKONOMI DAN BISNIS}

Sekertaris Unit Penjamin
Mutu

Ketua Unit Penjamin Mutu

Ketua Program Studi

Ketua Laboratorium

Sekertaris Jurusan

Ketua Jurusan

Kasubag. Akademik

Kasubag. Umum \& BMN

Kasubag. Keuangan \& Kepegawaian

Kasubag. Akademik

Kabag. Tata Usaha

Wakil Dekan III

Wakil Dekan II

Wakil Dekan I

Dekan

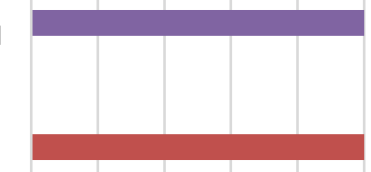

0\% $20 \% \quad 40 \%$ 60\% 80\% 100\%120\%

- Perempuan Laki-laki

Gambar 11. Persentase Gender pada Fakultas

Ekonomi dan Bisnis UNSRAT (Sumber:

Data Primer UNSRAT dalam angka 2018)

Fakultas Ekonomi dan Bisnis, terlihat dominasi laki-laki dalam pemegangan posisi dan jabatan di kepemimpinan fakultas. Namun tidak sedikit pula perempuan yang ikut andil dalam pemegangan posisi dan jabatan pada kepemimpinan di sana.

\section{Fakultas Hukum}

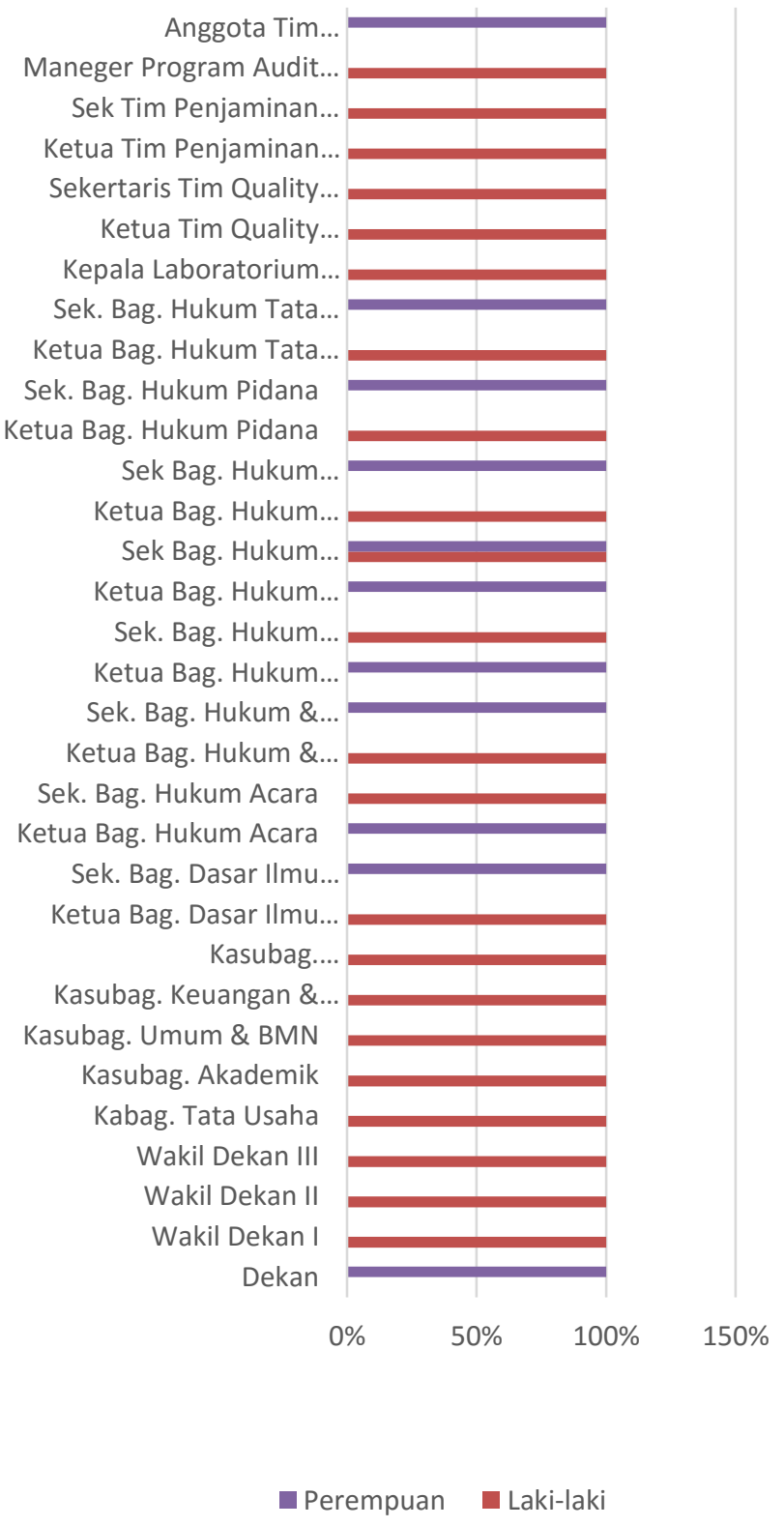
Gambar 12. Persentase Gender pada Fakultas Hukum UNSRAT (Sumber: Data Primer UNSRAT dalam angka 2018)

Fakultas Hukum, terlihat dominasi laki-laki dalam pemegangan posisi dan jabatan di kepemimpinan fakultas. Namun tidak sedikit pula perempuan yang ikut andil dalam pemegangan posisi dan jabatan pada kepemimpinan di sana. 
Jurnal Perempuan dan Anak Indonesia

\section{Fakultas Ilmu Sosial dan Politik}

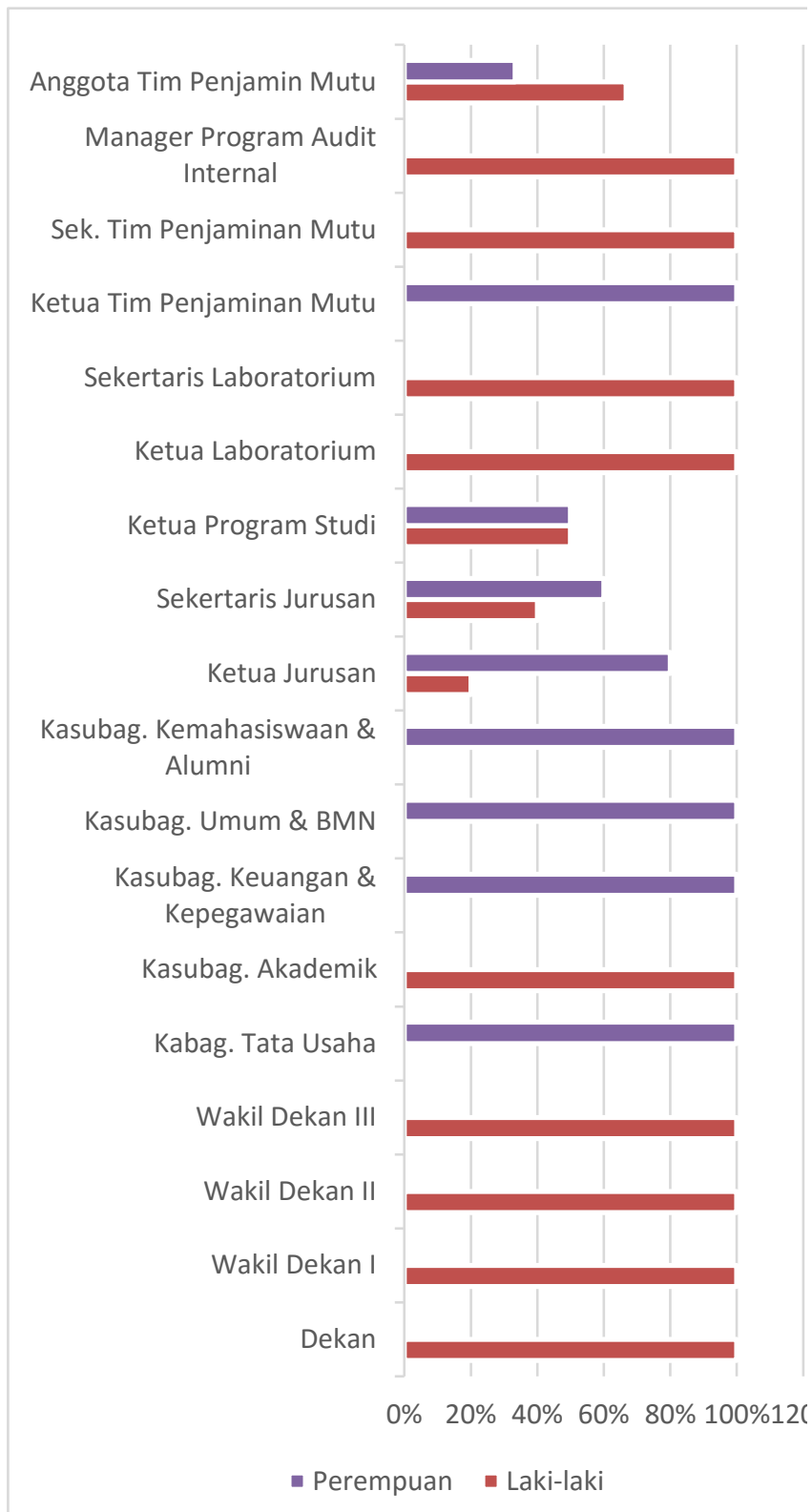

Gambar 13. Persentase Gender pada Fakultas Ilmu Sosial dan Politik UNSRAT (Sumber: Data Primer UNSRAT dalam angka 2018)

Fakultas Ilmu Sosial dan Politik, terlihat pemegangan posisi dan jabatan di kepemimpinan fakultas seimbang antara laki-laki dan perempuan. Kesetaraan gender pada fakultas ini pada pemegangan posisi dan jabatan terlihat sangat jelas.

\section{Fakultas Ilmu Budaya}

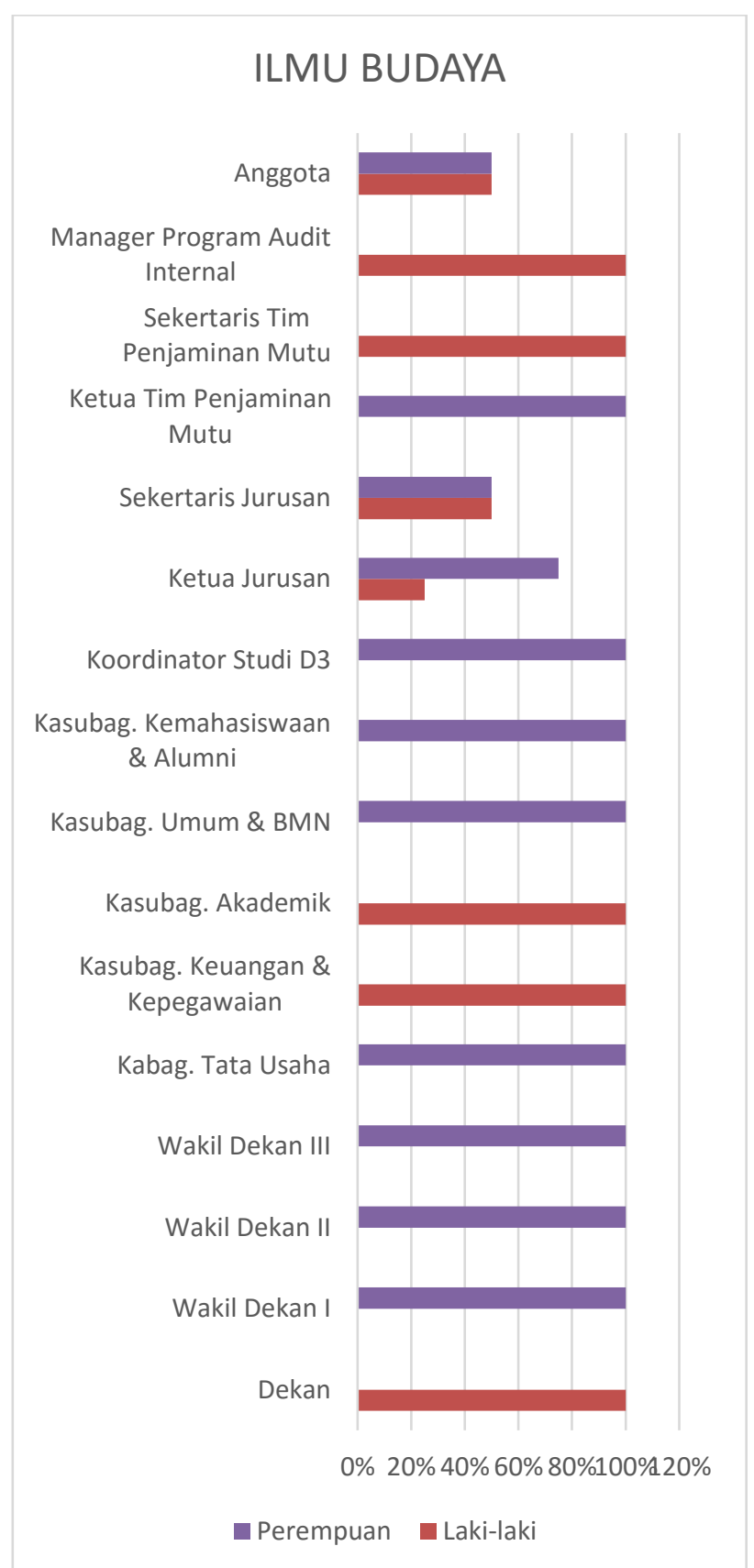

Gambar 14. Persentase Gender pada Fakultas Ilmu Budaya UNSRAT (Sumber: Data Primer UNSRAT dalam angka 2018)

Fakultas Ilmu Budaya, terlihat dominasi perempuan dalam pemegangan posisi dan jabatan di kepemimpinan fakultas. Namun tidak sedikit laki-laki yang ikut andil dalam pemegangan posisi dan jabatan pada fakultas ini. 
Jurnal Perempuan dan Anak Indonesia

\section{Fakultas Matematika dan Ilmu Pengetahuan Alam}

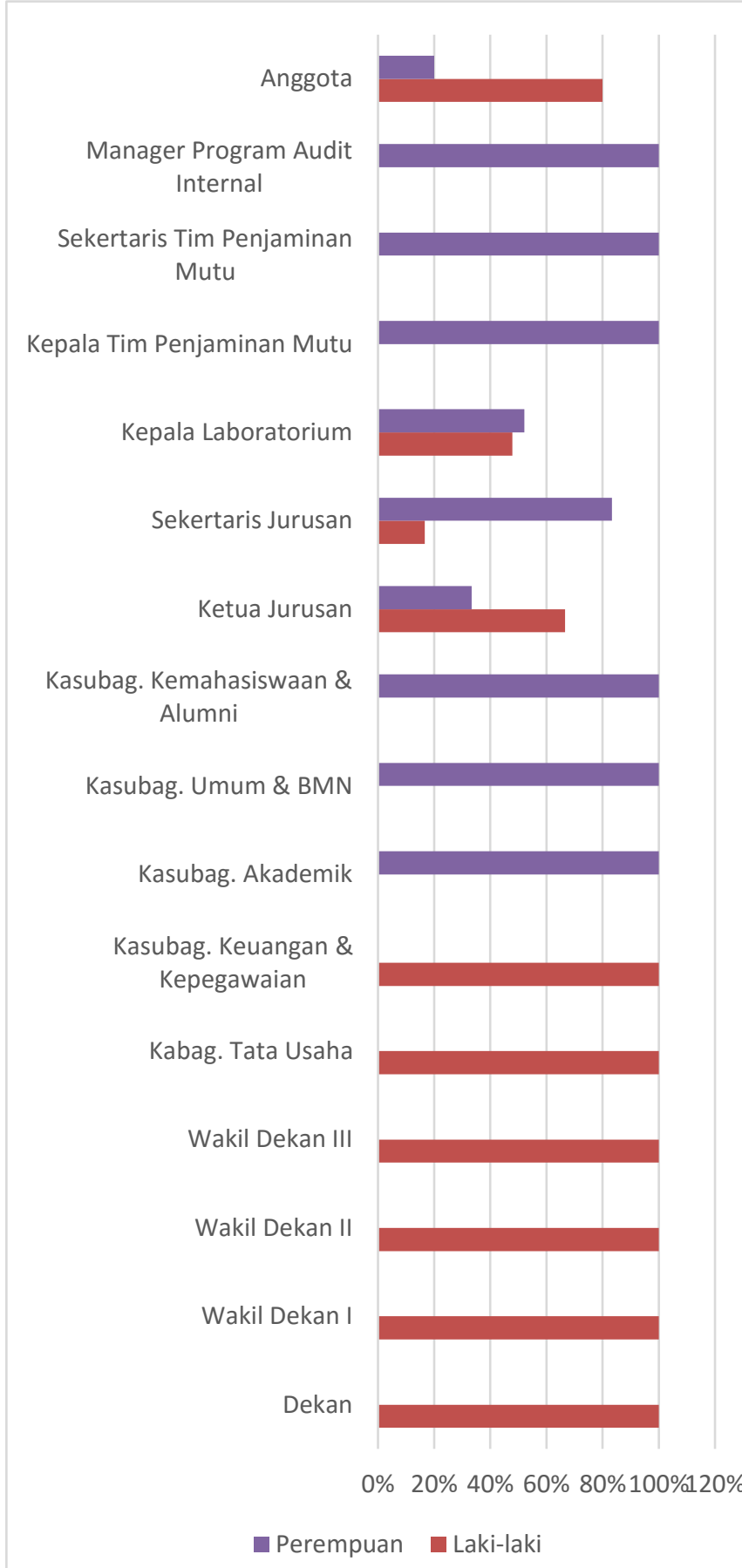

Gambar 15. Persentase Gender pada Fakultas

Matematika dan Ilmu Pengetahuan Alam UNSRAT (Sumber: Data Primer UNSRAT dalam angka 2018)

Fakultas Matematika dan Ilmu Pengetahuan Alam (MIPA), terlihat pemegangan posisi dan jabatan di kepemimpinan fakultas seimbang antara laki-laki dan perempuan. Kesetaraan gender pada fakultas ini terlihat sangat jelas.

\section{Fakultas Kesehatan Masyarakat}

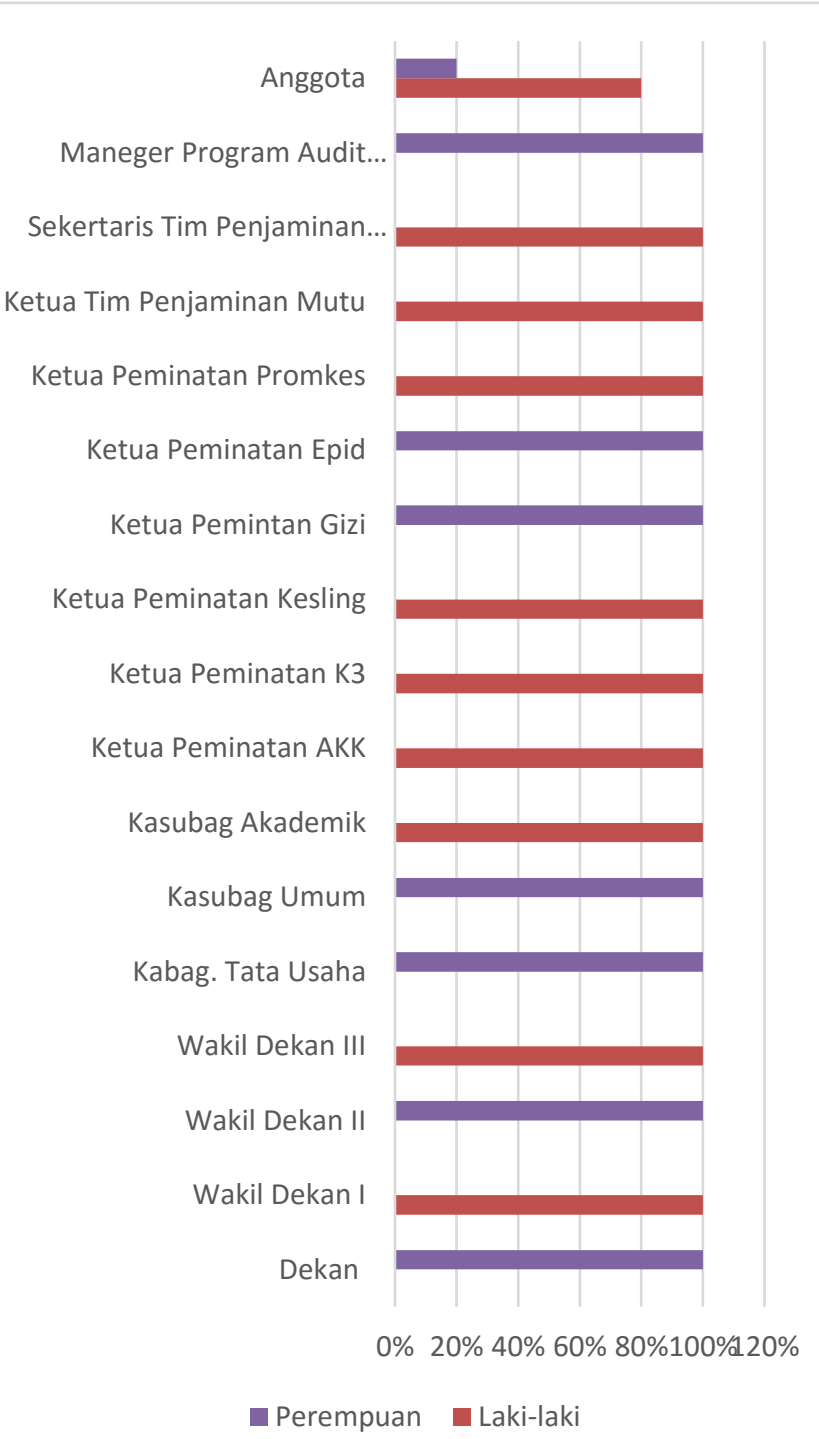

Gambar 16. Persentase Gender pada Fakultas Kesehatan Masyarakat UNSRAT (Sumber: Data Primer UNSRAT dalam angka 2018)

Fakultas Kesehatan Masyarakat, terlihat dominasi laki-laki dalam pemegangan posisi dan jabatan di kepemimpinan fakultas. Namun tidak sedikit pula perempuan yang ikut andil dalam pemegangan posisi dan jabatan pada kepemimpinan fakultas ini.

\section{Pasca Sarjana}

Di Lembaga Pasca Sarjana UNSRAT masih terjadi ketimpangan posisi jabatan oleh laki-laki. Berdasarkan data, direktur pasca sarjana adalah laki- 
laki dan dua wakil direkturnya adalah laki-laki dan perempuan. Wakil direktur ini bekerja untuk membantu direktur pasca sarjana. Sementara itu, staf pasca sarjana 58\% laki-laki dan $42 \%$. Koordinator program studi pada pasca sarjana terdiri 8 posisi, 6 posisi diduduki oleh laki-laki dan 2 posisi dijabat oleh perempuan.

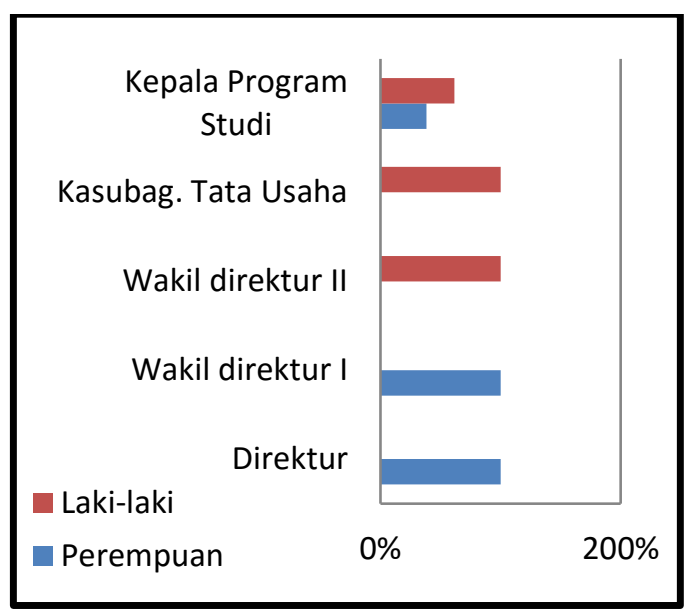

Gambar 17. Perbandingan Gender di Pasca Sarjana UNSRAT Sumber: Data Primer UNSRAT dalam Angka, 2018

Meskipun pada tingkat wakil direktur I dan wakil direktur II agak menemui titik keseimbangan namun pada bagian penting yang lain yaitu kepala program studi keadaan masih menunjukkan adanya kesenjangan gender. Pasca sarjana adalah unit penting karena didalamnya diproduksi jenjang pendidikan yang lebih tinggi yakni tingkatan magister dan doktor, maka apabila pengajaran dan pengorganisasian tingkat pasca sarjana ini memenuhi kesetaraan gender akan bisa mendorong terpenuhi kesetaraan gender pada tenaga pendidik pada level S1, S2 maupun S3 dapat dilihat pada Gambar 17.

\section{Lembaga Penjamin Mutu}

Lembaga Penjaminan Mutu (LPM) merupakan organ penting dalam UNSRAT terutama karena mandatnya yang berkewajiban menjamin mutu UNSRAT baik pada segi capaian akademik, riset dan pengabdian masyarakat. Komposisi gender dalam lembaga ini juga masih didominasi laki-laki. Dalam beberapa pertemuan dengan pengurus LPM, Nampak bahwa lembaga ini memang sangat strategis sebagai pelaku integrasi gender selain PKP untuk bidang kurikulum. Dalam beberapa hal, LPM bisa mengintegrasikan gender melalui model Satuan Pembelajaran (SAP) yang kini sedang dikembangkan model kurikulum integrasi gender. Lebih jelas dapat lilihat pada Gambar 18.

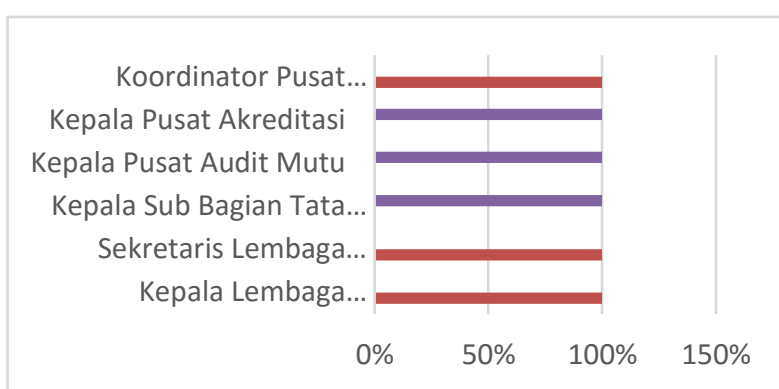

Gambar 18. Perbandingan Gender di Lembaga Penjaminan Mutu UNSRAT (Sumber: Data Primer UNSRAT dalam Angka, 2018)

\section{Lembaga Penelitian Dan Pengabdian Kepada Masyarakat}

Lembaga Penelitian dan Pengabdian kepada Masyarakat (LPPM) adalah lembaga yang paling strategis di UNSRAT. Bisa dikatakan LPPM adalah tulang punggung kemajuan UNSRAT dalam bidang penelitian dan pengabdian kepada masyarakat.

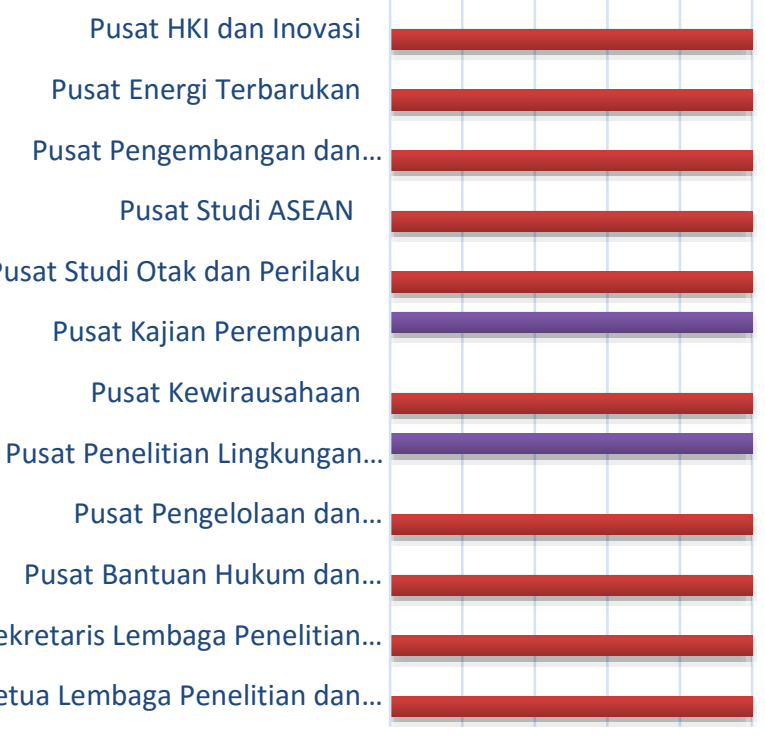

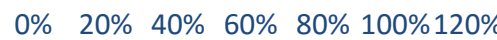

Gambar 19. Perbandingan Gender di Lembaga Penelitian dan engabdian Kepada Masyarakat UNSRAT

(Sumber: Data Primer UNSRAT dalam Angka, 2018)

Susunan LPPM berbeda-beda dari satu universitas ke universitas lainnya. LPPM UNSRAT sendiri membawahi sepuluh pusat; Pusat Bantuan Hukum dan HAM, Koord Pusat Pengelolaan dan 
Pengembangan KKNT, Pusat Penelitian Lingkungan Hidup dan SDA, Pusat Pengembangan Kewirausahaan, Pusat Kajian Wanita, Pusat Studi Otak dan Perilaku, Pusat Studi ASEAN, Pusat Pengembangan, Pelatihan Teknologi Informasi, Pusat Energi Terbarukan dan Pusat HKI dan Inovasi. Dari kesepuluh pusat ini, hanya terdapat dua posisi koordinator yang dijabat oleh Perempuan yakni Pusat Penelitian Lingkungan Hidup dan SDA dan Pusat Kajian Perempuan. Sementara pusat yang lain dipegang oleh laki-laki. Penempatan perempuan sebagai koordinator pada PKP dan laki-laki pada koordinator lain di bawah LPPM adalah semacam konvensi. Mestinya, bisa saja suatu saat perempuan memimpin koordinator lain selain PKP dan bisa saja suatu saat laki-laki memimpim PKP. Adapun komposisi personal kepengurusan dalam lembagalembaga di bawah LPPM sebagaimana dalam Gambar 19.

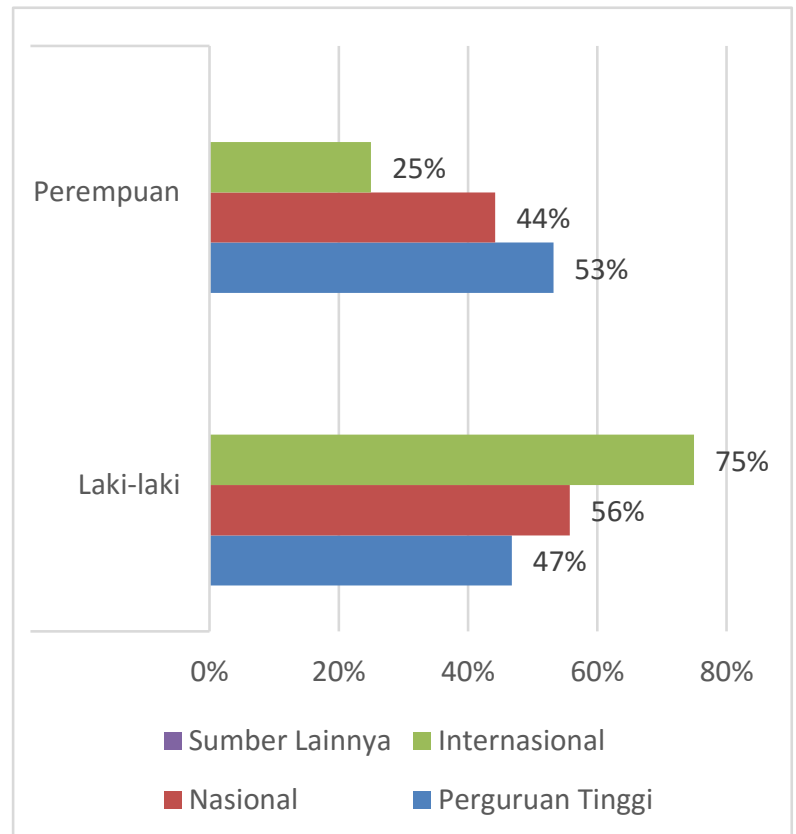

Gambar 20. Perbandingan Gender enerima Dana

Penelitian UNSRAT Tahun 2018 (Sumber LPPM Unsrat)

Dari data yang ada, dosen perempuan yang menerima dana penelitian masih rendah khususnya pada penerimaan dana penelitian internasional dan nasional. Dosen perempuan yang menerima dana penelitian internasional hanya $25 \%$ saja sedangkan dosen laki-laki sudah mencapai 75\%. Dosen perempuan penerima penelitian nasional sebesar $44 \%$ dan dosen laki-laki sebesar 56\%. Angka persentasi yang tinggi bagi dosen perempuan terdapat pada penerima penelitian perguruan tinggi yakni sebesar
53\% sedangkan dosen laki-laki sebesar 47\% (Gambar 20).

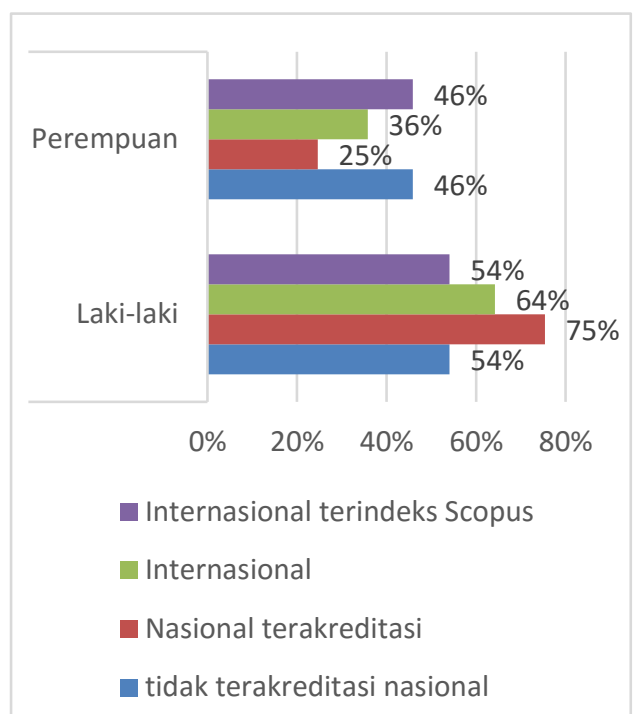

Gambar 21. Perbandingan Gender Dosen UNSRAT Berdasarkan Jumlah Publikasi dan Sitasi (Sumber LPPM Unsrat)

Terkait publikasi ilmiah, dosen perempuan lagi-lagi berada di posisi kedua. Dosen perempuan yang memiliki jurnal nasional tidak terakreditasi sebanyak $46 \%$ sedangkan dosen laki-laki sebanyak $54 \%$. Dosen perempuan yang memiliki jurnal nasional terakreditasi sebanyak $25 \%$ sedangkan dosen laki-laki sebanyak $75 \%$. Dosen perempuan yang memiliki jurnal internasional sebanyak $36 \%$ sedangkan dosen laki-laki sebanyak 64\%. Dan dosen perempuan yang memiliki jurnal internasional terindeks Scopus sebanyak 48\% dan dosen laki-laki sebanyak 54\% (Gambar 21).

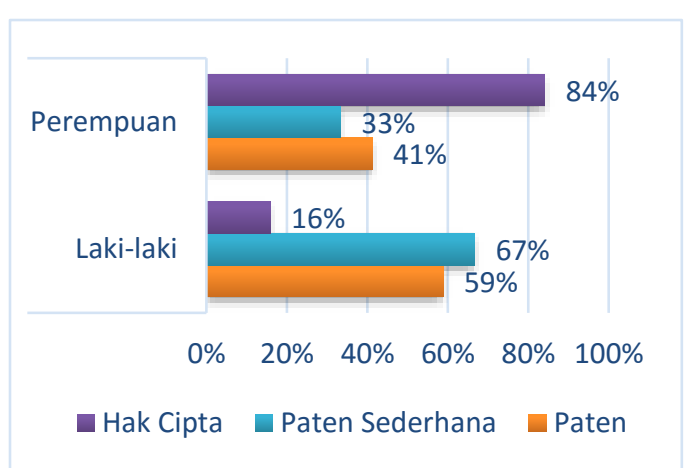

Gambar 22. Perbandingan Gender Dosen

Berdasarkan Kekayaan Intelektual yang Dimiliki (sumber LPPM Unsrat)

Terkait kekayaan intelektual untuk menghasilan paten, paten sederhana, dan hak cipta, 
dosen perempuan hanya unggul dalam menghasilkan hak cipta yaitu sebanyak $84 \%$ sedangkan dosen lakilaki sebanyak $16 \%$. Namun pada paten dan paten sederhana lagi-lagi dosen laki-laki lebih unggul yakni untuk paten sederhana sebanyak 67\% sedangkan dosen perempuan sebanyak 33\%. Dalam menghasilan paten, dosen laki-laki sebanyak 59\% sedangkan dosen perempuan sebanyak $41 \%$.

\section{Lembaga Pembinaan Dan Pengembangan Pembelajaran}

Lembaga Pembinaan dan Pengembangan Pembelajaran (LP3) di UNSRAT terdiri atas beberapa pusat, yaitu Pusat Kajian Pengembangan dan Evaluasi Kurikulum Pembelajaran, Pusat Kajian Pengembangan dan Evaluasi Administrasi dan Managemen Pembelajaran, Pusat Pembinaan Mata Kuliah Pembinaan Kepribadian (PPP-MK), dan Pusat Karir Dan Trace Study. Dari keempat pusat ini hanya 1 pusat yang dikoordinatori oleh perempuan. Pimpinan lembaganya, baik ketua dan sekretaris dijabat oleh laki-laki. Baiknya untuk puncak pimpinan suatu lembaga ada kesetaraan gender, tidak didominasi oleh salah satunya. Lebih jelasnya dapat dilihat pada Gambar 23.

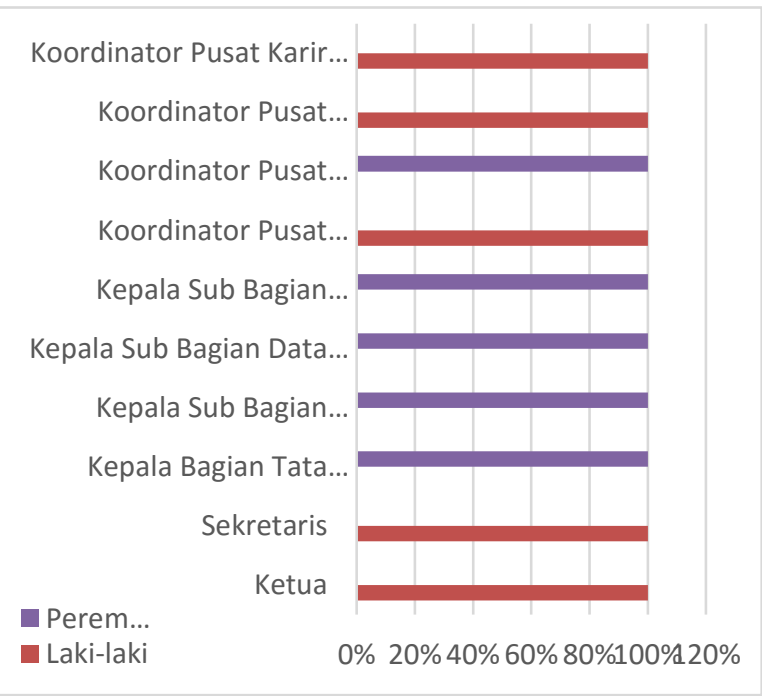

Gambar 23. Perbandingan Gender di Lembaga

Pembinaan dan Pengembangan Pembelajaran UNSRAT (Sumber: Data Primer UNSRAT dalam Angka, 2018)

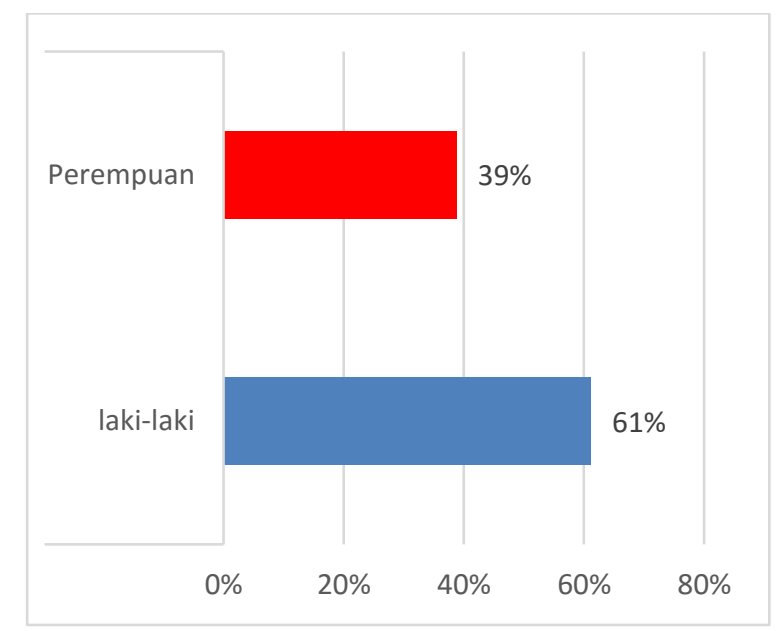

Gambar 24. Perbandingan Gender Dosen

Berdasarkan Jumlah Buku Ajar yang

Dihasilkan (Sumber LPPM Unsrat)

Kegiatan pembuatan buku ajar menjadi kebutuhan pokok dalam proses belajar mengajar. Para dosen di UNSRAT pun telah meresponnya. Dari data yang ada, dosen perempuan masih kurang dalam pembuatan buku ajar yaitu hanya sebanyak 39\% dan dosen laki-laki sebanyak $61 \%$ yang membuat buku ajar (Gambar 24)

\section{Unit Pelaksana Teknis}

Hal yang dilihat dalam gender assessment ini adalah profil gender dalam Unit Pelaksana Teknis. Jumlah UPT di lingkungan UNSRAT ada 8 UPT; (1) Perpustakaan, (2) Teknologi Informasi dan Komunikasi, (3) Pengembangan dan Pelatihan Bahasa, (4) Layanan Internasional, dan (5) Pusat Kearsipan, (6) Laboratorium Terpadu, (7) Percetakan dan Penerbitan, dan (8) Bimbingan dan Konseling.

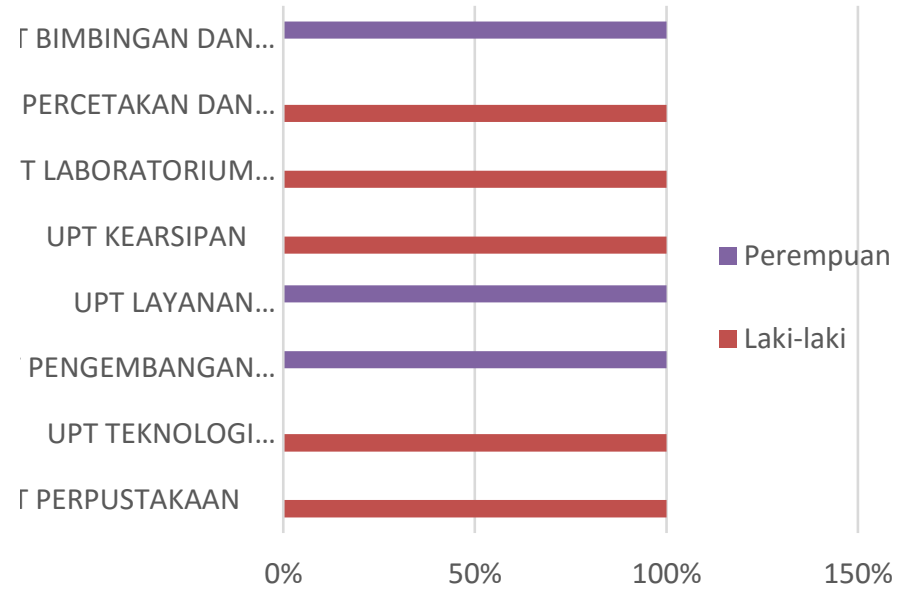

Gambar 25. Perbandingan Gender di UPT UNSRAT Sumber: Data Primer UNSRAT dalam Angka, 2018 
Dari kedelapan unit pelaksana teknis ini, posisi perempuan sebagai koordinator ada pada unit usaha-unit usaha yang secara bisa diasosiasikan dengan posisi yang seharusnya diduduki oleh perempuan. Dalam hal ini misalnya adalah posisi perempuan sebagai Koordinator UPT Bimbingan dan Konseling. Berdasarkan data yang tersedia, ada semacam kecenderungan bahwa perempuan sulit menduduki jabatan-jabatan yang biasanya dipahami sebagai jabatan laki-laki. Tentang ini diperlihatkan pada Gambar 25.

\section{KESIMPULAN}

Berdasarkan temuan dan analisis pada gender assessment $\mathrm{di}$ atas, maka beberapa poin direkomendasikan untuk diaplikasikan di institusi UNSRAT Manado sebagai berikut:

1. Proporsi kepemimpinan di UNSRAT harus mempertimbangkan representasi gender baik di tingkat universitas, fakultas, lembaga, maupun unit dan lembaga kemahasiswaan dalam lingkup universitas,

2. Perlu mengafirmasi keseimbangan jumlah mahasiswa berdasarkan kesetaraan gender karena ada pelabelan pada prodi-prodi tertentu, seperti Fakultas Teknik lebih banyak laki-laki dibanding prempuan, di Fakultas Kesehatan Masyarakat lebih banyak perempuan dibandingkan laki-laki demikian fakultas-fakultas yang lain.

3. Meminta kepada pimpinan universitas untuk membangun sarana dan prasarana kampus yang responsif gender.

4. Perlu dilakukan kegiatan-kegiatan untuk meningkatkan kesadaran dan kapasitas civitas akademika dalam penerapan isu gender, misalnya workshop integrasi gender ke dalam kurikulum, workshop penulisan proposal berbasis gender.

5. Anggaran penelitian untuk pembiayaan kegiatan gender masih sangat kurang dan perlu peningkatan paling tidak mendekati sesuai dengan kuota nasional.

6. Perlu ditingkatkan publikasi hasil penelitian berbasis gender dalam bentuk jurnal nasional maupun internasional.

\section{UCAPAN TERIMA KASIH}

Ucapan terima kasih atau bantuan dana dan fasilitasi yang diberikan oleh Kementerian Pemberdayaan Perempuan dan Anak (KPPA) Deputi Partisipasi Agama dan Masyarakat yang telah bekerjasama dengan Pusat Kajian Perempuan Lembaga Penelitian dan Pengabdian Universitas Sam
Ratulangi Manado dengan kontrak kerjasama nomor PKS-087/KPP-PA/Dep. V/Asd.3/10/2019 pada tanggal 1 Oktober 2019 yang ditanda tangani oleh Ketua LPPM UNSRAT dan Deputi Partisipasi Agama dan Masyarakat.

\section{DAFTAR PUSTAKA}

Berita Manado.com. 2019. Rektor UNSRAT Ellen Kumaat Pemenang Academic Leaderhttps://beritamanado. com/rektorUNSRAT-ellen-kumaat-pemenang-academicleader/ (akses 12 November 2019)

Direktorat Jenderal Sumber Daya Ilmu Pengetahuan Teknologi dan Pendidikan Tinggi Kementerian Risat, Teknologi dan Pendidikan Tinggi menyelenggarakan Penghargaan Academic Leader 2019.

Hartini, Abdillah Mustari, Ani Auli Ilmi, Fatmawati Mallapiang, Himayah, 2016. Gender Di Kampus Kami: Penilaian Kesetaraan Gender di lingkungan Awalauddin Makassar. Nur khairunnisa.

Manadonews. 2019. Rektor Terbaik Indonesia, Ellen Kumaat Juara 1 Academic Leader 2019. https://www.manadonews.co.id/2019/10/02/rek tor-terbaik-indonesia-ellen-kumaat-juara-1academic-leader-2019/

\section{Renstra UNSRAT 2015-2019}

Unsrat dalam Angka Tahun 2018.

UNSRAT. 2019. Rektor Prof. Dr. Ir. Ellen J. Kumaat, MSc., DEA menjadi yang terbaik dalam Academic Leader Award 2019. ttps://www.UNSRAT.ac.id/ Berita/detail/Peristiwa/rektor-prof-dr-ir-ellen-jkumaat-msc-dea-menjadi-yang-terbaik-dalamacademic-leader-award-2019 